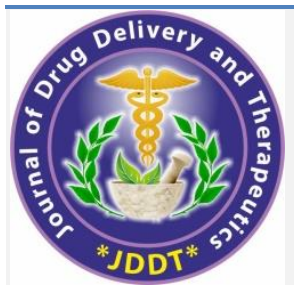

Open Access Full Text Article
Available online on 15.09.2021 at http://jddtonline.info

\section{Journal of Drug Delivery and Therapeutics}

Open Access to Pharmaceutical and Medical Research

Copyright (C) 2021 The Author(s): This is an open-access article distributed under the terms of the CC BY-NC 4.0 which permits unrestricted use, distribution, and reproduction in any medium for non-commercial use provided the original author and source are credited

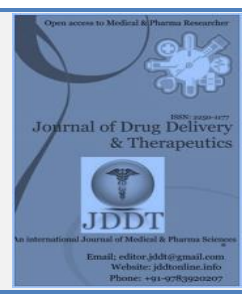

Review Article

\title{
Food Allergies and Homoeopathy: A Narrative Review
}

\author{
Vaishali H. Shinde ${ }^{1 *}$ (D) , Dr. Ramesh Bawaskar ${ }^{1}$, Dr. K.C. Muraleedharan ${ }^{2}$
}

${ }^{1}$ Research Officer (H.)/Scientist-3, Regional Research Institute for Homoeopathy, Mumbai under Central Council for Research in Homoeopathy, Ministry of AYUSH Govt. of India.

${ }^{2}$ Assistant Director (H.), National Homoeopathy Research Institute in Mental Health, Kottayam, Kerala

\begin{tabular}{ll}
\hline Article Info: & \\
\hline & Article History: \\
&
\end{tabular}

\section{Cite this article as:}

Shinde VH, Bawaskar R, Muraleedharan KC, Food Allergies and Homoeopathy: A Narrative Review, Journal of Drug Delivery and Therapeutics. 2021; 11(5):213-220

DOI: $h$ ttp://dx.doi.org/10.22270/jddt.v11i5.5040

\section{Abstract}

Allergy, formally called type I (or immediate) hypersensitivity is one of four or more forms of hypersensitivity manifesting in various forms like, Atopic eczema, Allergic urticaria, Allergic rhinitis, Allergic asthma, , Food allergy, etc. The growing incidence of Food allergy needs attention since its burden is mainly on children and adolescents. Various factors has been attributed to the growing incidence of food allergy such as food habits, cooking habits, cultural differences, various developmental parameters and exchange of food products. The World Allergy Organization has estimated 220 to 550 million people suffering from food allergy with a large chunk of population from the developed countries. No concrete data is available on status of food allergy in India though some sporadic research has been published. In spite of diligent research worldwide, an effective mechanism to cure this condition has not been evolved till today. Since effectiveness of homeopathy has been proved in various allergy conditions, the modality of using the same has been explored in this article.

Keywords: Food allergy, Homoeopathy, Type I hypersensitivity

\section{*Address for Correspondence:}

Vaishali H. Shinde, Research Officer (H.)/Scientist-3, Regional Research Institute for Homoeopathy, Mumbai under Central Council for Research in Homoeopathy, Ministry of AYUSH Govt. of India.

ORCID ID: https://orcid.org/0000-0001-8707-5942

\section{Introduction:}

Hypersensitivity reactions are an outcome of an exaggerated immune and inflammatory response. Allergy, formally called type I (or immediate) hypersensitivity is one of four or more forms of hypersensitivity manifesting in various forms like, Atopic eczema, Allergic urticaria, Allergic rhinitis (Hay fever), Allergic asthma, Anaphylaxis, Food allergy, etc which involves immunoglobulin E (IgE) mediated release of antibodies against the soluble antigen. ${ }^{1}$

Food Allergies (FAs) are common in modern world. The incidence has increased many folds due to changed lifestyles and food habits. ${ }^{2}$ The FAs are one of the prominent health problems of all over world especially in children and adolescent age group. The National Institute of Allergy and Infectious Disease (NIAID), USA has defined the food allergy as "adverse health effect arising from a specific immune response that occurs reproducibly on exposure to a given food". The international guidelines distinctively differentiated the FA from food intolerance which is usually mistaken as food allergy. A "food" defined according to NIAID is "any substance -whether processed, semi processed, or raw - that is intended for human consumption, and includes drinks, chewing gum, food additives and dietary supplements." Various products like drugs, tobacco products and ingested cosmetics are not included in the list. ${ }^{3}$

This review is aimed to disseminate the evolutionary milestones of food allergy, its metamorphosis into a growing health concern, failure of an effective mechanism of intervention and projection of an alternative approach to tackle the growing menace of food allergy worldwide. The reader is expected to appreciate the current modalities and projection of its exploration and validation through homoeopathic medicines which reciprocally benefits both homoeopathy as well as the food allergy patients. Since this is primarily focusing on the basic concepts, the PRISMA Statement has not been applied in preparing this article. 4

Though the FA is a modern term for the allergic reaction to a food item, ancient literatures abundantly described about effects of food on human beings. The ancient Ayurveda writings especially, Charaka Samhita $(200$ BC $)$ had mentioned of "Virudh Ahara". This means incompatible food that should be avoided and if taken together could potentially harm the person's health. This could be the first comprehensive depiction of adverse effect of food on human body. More over Charaka Samhita has detailed description on how, when, and what to be taken as food. ${ }^{5}$ Food reactions were also recorded way back in Hippocrates writings. ${ }^{6,7}$ So it 
is evident that the food and its adverse effects on human beings were not alien to the ancient physicians.

Though the term Food reactions might have been coined with the new terminology of "Allergy" which was first used in 1906 by Clemens von Pirquet, an Austrian Scientist and Pediatrician, there were many scientists who have identified food as an important factor for various disease conditions. ${ }^{8}$
The "Food factor in Disease" in two volumes published in 1905 by Francis Hare is one of the comprehensive writing about the topic and it has discussed in detail about various disease conditions arising out of food habits. ${ }^{9}$

Many more publications have come up on food allergy authored by various scientists time to time and they have considered the food as therapeutic purpose as well as some projected the allergy factors in food. Important milestones in the Food allergy literature are mentioned in the Table 1.

Table 1 Important early publication's in food allergy

\begin{tabular}{|c|c|c|}
\hline Author & Title of publications & Year \\
\hline Dr. Albert Row & Food allergy: Its manifestations, Diagnosis and treatment & 1931 \\
\hline Dr. Rowe A. H., Rowe A. Jr & $\begin{array}{l}\text { Food Allergy: Its Manifestations and Control and the Elimination Diets; a } \\
\text { Compendium. With Important Consideration of Inhalant (Especially Pollen), Drug, } \\
\text { and Infectant Allergy }\end{array}$ & 1972 \\
\hline Dr.Warren Taylor Vaughan & Vaughan, Warren Taylor. Strange Malady: the Story of Allergy & 1941 \\
\hline Dr.Warren Taylor Vaughan & Practice of allergy & 1948 \\
\hline Dr.Arthur F Coca & Familial Non-Reagenic Food Allergy & 1942 \\
\hline Dr.Arthur Rinkel & Food Allergy & 1951 \\
\hline Dr.Arthur F Coca & Pulse Test & 1956 \\
\hline Theron G Randolph & Human Ecology and susceptibility to the chemical environment & 1962 \\
\hline Theron G Randolph & $\begin{array}{l}\text { An alternative approach to allergies: } \\
\text { The new field of clinical ecology unravels the environmental causes of mental and } \\
\text { physical ills }\end{array}$ & 1980 \\
\hline Theron G Randolph & Environmental medicine: beginnings and bibliographies of clinical ecology & 1987 \\
\hline
\end{tabular}

Dr. Theron G Randolph, an environmental and allergy specialist was controversial and blamed the chemicals and polluted environment for the cause of Allergies. This was disapproved earlier by many scientists citing lack of scientific proofs but later his contribution had been accepted.

Dr.Arthur F Coca, one of the renowned scientists in the field of Allergy has suggested "Pulse test" to analyze the pulse of a person on morning, on retiring, before food and 30 minutes after food for three times for three days. The average will be analyzed in respect to the food ingested and try to find out the allergic food items from the menu. ${ }^{10}$

The development of immunology further gave strength to the components of the allergy factors in the body. The discovery of Immunoglobulin E by Kimishige Ishizaka, Japanese scientist in 1966 has given more scientific basis for allergy as a disease entity especially in respect to the food.11 With the development and modernization of the society, the food allergy became one of the important health problems in various countries. The incidence of Food allergy found to be reported more from the developed countries than underdeveloped or developing countries. ${ }^{12}$

\section{Classification of food allergy and diagnosis:}

FA reactions have been divided broadly into Immunoglobulin E (IgE) mediated and non-immunoglobulin E mediated allergies. IgE mediated are immediate onset reactions and immediate plus late phase where reaction is immediate with prolonged symptoms. Non IgE mediated reactions are believed to be $\mathrm{T}$ cell mediated but not defined scientifically. The onset of the reaction occurs 4-28 hours after ingestion of food. Intolerance is the term used for non immune reactions such as drug reactions and lactose intolerance. ${ }^{13}$

The diagnosis of FA is currently made through the conventional Skin Prick test (SPT) and serum-specific IgE testing (sIgE).But both this tests lack accuracy and do not predict the intensity of allergic reactions. ${ }^{14}$ No standardized test is currently available for the non-IgE mediated food allergies.

\section{Prevalence of Food allergy and its implications:}

The growing incidence of food allergies all over the world is evident from data gathered. Children are more prone to develop the food allergy especially in the first year of birth (5-8\%) than the adults (1-2\%). The World Allergy Organization has estimated that 220 to 550 million people are suffering from food allergy. ${ }^{15}$ The exports, more interaction between counties, more exchange of food products and food outlets which are basically strange to the existing food culture of that country could have been created a multifaceted health problem of food allergy, 16 though there is growing evidence, country wise systematic data is not available.

The highest prevalence of FA is reported from Australia and New Zealand. As per the CDC data, children are the highest victims of food allergy than the adult population without much variation in sex ratio. About 3.9 million US children below the age of 17 years have food allergy and high prevalence in below 5years of age. A latest survey in US has 
projected $8 \%$ children are allergic to various food items. In $90 \%$ of allergic reactions of food are due to ingestion of milk, eggs, peanuts, tree nuts, fish, shellfish, soy and wheat. It is estimated that the food allergic children are at high risk of getting other allergic conditions like Asthma and eczema.17, 18, 19. Country wise pooled data of prevalence of food allergy has been tabulated in Table 2 .

Table 2 Pooled country wise data on prevalence of food allergy

\begin{tabular}{|l|l|l|}
\hline Country & $\begin{array}{l}\text { Prevalence- } \\
\text { Children }\end{array}$ & $\begin{array}{l}\text { Prevalence - } \\
\text { Adult }\end{array}$ \\
\hline Australia & $10 \%$ & $1.3 \%$ \\
\hline New Zealand & $11 \%$ & $1.3 \%$ \\
\hline Canada & $5-6 \%$ & $3-4 \%$ \\
\hline France & $6-8 \%$ & $3.24 \%$ \\
\hline Greece & $6-8 \%$ & $4 \%$ \\
\hline Germany & $3-6 \%$ & $3 \%$ \\
\hline
\end{tabular}

There is no concrete data available on FA in India. Few clusterered data has been published on certain food items which caused allergy in indian population. A case report on Chick pea allergy has been reported by Niphadkar PV et al. ${ }^{20}$ Rural population in India has reported a very low food allergy than the urbanized population,21 Another study suggested a prevalence of food allergy in older children and adults of $4.5 \%$ in India. ${ }^{22}$ An epidemiological study based on the different culture, food preference, socioeconomic strata etc. need to be analyzed in a multi cultured population like India. Since the children are the victims of the FA in most of the countries, relevance of the study is increased many fold.

The prevalence of the FA is highly variable according to the culture, socio-economic development, age group and specific food items. In Japan soybean allergy is more whereas fish allergy is more prevalent in Scandinavian countries. EuroPrevall birth cohort study conducted among 12049 new born and their families from different European countries suggested there are great variations in country to countries data. Self reported food reactions were highest amoung German mothers (30\%), and Iceland, UK and Netherelands have $20-22 \%$ of food reactions. Whereas Italy, Poland, Greece etc have shown 5-8\%.23

The major implication of FA in health is anaphylaxis.Though most of the food allergy reactions are minor,anaphyalaxis is one of the major concern for the medical field since this has increased alarmigly in population. In UK the rate of anaphylaxis increased from 5 to 36 per million between 1990-2004. Australia has also high number of hospitalisation and in USA, it has been estimated that food allergy is responsible for 30,000 anaphylaxis episodes/year, leading to 2,000 hospitalizations and 200 deaths. ${ }^{17}$

Apart from the anaphylaxis reactions, major burden on children are developmental anomalies in respect to growth, malnutrition which is essentially observed in children having milk allergy and multiple food allergy reactions. ${ }^{24}$ Nutritional impact on elimination diet in cow's milk allergy was studied and found that weight-for-length index of patients decreased compared with those in healthy age-matched children. ${ }^{25}$ Severe Kwashiorkor was reported from United States due to avoidance of milk perceived to be caused dermatitis in an infant. ${ }^{26}$ Multiple food allergies are associated with defective growth and development of the child due to restricted diet. ${ }^{27}$
Many allergic disease conditions have been linked to food allergies especially in children with atopic dermatitis, asthma and serous otitis media. Conditions such as urticariaangioedema, contact dermatitis; upper and lower respiratory conditions like rhinitis and laryngeal edema, gastrointestinal disorders like oral allergy syndrome (OAS), infantile colics, nausea, vomiting, diarrhoea, abdominal pain and various neurological symptoms are also linked to FA. 28,29,30,31.

Apart from various health related conditions, the economic burden of food allergy is also to be addressed. The economic implication in USA has been derived that in 2007, "direct medical costs were $\$ 225$ million, and indirect costs were $\$ 115$ million. Office visits accounted for $52.5 \%$ of costs, and the remainder was split between emergency visits (20\%), inpatient hospitalizations (11.8\%), outpatient visits (3.9\%), ambulance runs (3\%), and epinephrine devices $(8.7 \%)$ ". "Simulations from probabilistic sensitivity analyses suggested mean direct medical costs were \$307 million and indirect costs were $\$ 203$ million",32 no data has been available on Indian health care.

\section{Risk factors of food allergy}

The mechanism of food allergy has been widely researched in western world and established an immunological phenomenon, unequivocally. There are several contributing factors established which is varied from cultural deviation to socioeconomic development. However IgE mediated food allergy are frequently identified from intake of egg, milk, peanut, nuts, fish and soya in children, and peanuts, nuts, fish and shellfish in adults. But an exact reason behind allergenicity to certain food is not yet established.

Apart from the Immunological factors, several contributing factors have been linked to FA. There are various studies suggesting vital role of hereditary link in FA among the parents or siblings having food allergy history. ${ }^{33,34}$

Another interesting finding which was overlooked or rather neglected by the profession is risk of FA is increased seven fold in children born to allergic mothers through caesarian section. ${ }^{35}$ Strong evidence has been established to the food habits in pre- and post natal food of the mother. ${ }^{34}$ Maternal factors like breast feeding for 3-6 months could reduce the risk of food allergy. 36

Cooking methods can also influence the allergenicty of food material which was established by the difference seen in boiled peanut and fried peanut used in China and in USA. The fried peanut has more allergic potential than the boiled used in China. ${ }^{37}$

Some gender inequalities have been observed in systematic review which showed male dominance in children and female dominance in adult having FA. ${ }^{38}$ But concrete evidence has not been elicited to prove the gender inequality of FA.

\section{Therapeutic Challenges in food allergy:}

Food allergy being one of the important conditions requiring even emergency medications puzzled the medical system for a comprehensive therapeutic approach. Modern medical world almost unanimously opted for the avoidance of the food which causes allergic reaction. But this is seldom adhered to people who are frequent travelers, and are bound to eat outside food and especially in children those who are not aware about the seriousness of their allergy. Another problem arising out from improper labeling of food stuffs which may contain allergic additives, allergic food stuffs etc. though India has a strong food safety regulation guidelines and rules. 39 
Avoidance or change of cooking habits, and alternative food habits are recommended by the medical field for providing food allergy free life. The curability of tendency to a particular allergen is presently not considered a viable approach by the modern medicine. Ancient medical system "Ayurveda" has detailed description on various food items but also preaches to avoid the food item. Most of the medical literatures talk about the avoidance of the allergic food items, change of food habits and selective intake which are essentially impractical when it comes to ground reality. Management of various food allergy factors is difficult especially when strong family inheritance is noticed. $40,41,42$.

Since the most vulnerable groups are the children, stopping them from taking their favorite food is not always possible. Prevention through the medical care was not properly explored in the medical world.

\section{Role and scope of Homeopathy:}

Homoeopathy is one of the modern and youngest medical sciences in the history of medicine. To develop Homoeopathy as a complete medical care facility, the nourishment of various branches of medicines through systematic research is imperative. Homoeopathy is evidentially suggestive of beneficial in boosting the immunological responses in conditions from allergies to neoplasms. ${ }^{43}$ Food allergy is one of the important therapeutic areas in homoeopathy which has very little been explored by the scientists or physicians. It is worth mentioning that the founder and father of Homoeopathy, Dr. Samuel Hahnemann has mentioned regulation of diet in acute as well as in chronic conditions. His Organon of Medicine has clearly instructed avoidance of food items which affect or alter the action of homoeopathic medicine and disease. Under aphorism 260 he writes "Hence the careful investigation into such obstacles to cure is so much the more necessary in the case of patients affected by chronic diseases, as their diseases are usually aggravated by such noxious influences and other disease-causing errors in the diet and regimen, which often pass unnoticed". 44

Food is considered to be an important and integral part in homeopathy as this is evident from the writing of Hahnemann and it is not strange to the homoeopaths that even certain craving, aversion and allergic condition to certain food items gives clue to the homeopathic prescriptions. There are 220 types of food aggravations and its possible medicines been listed in the "Complete repertory" compiled by Roger van Zandvoort. 45 There are several non-specific case reports been published by various authors like J.T.Kent, EB Nash, NM Chaudhari etc. through their various literature publications. Though most of the data is gathered prior to the identification of the immunological factors in FA, it is necessary to incorporate these valuable scientific markers in homoeopathic practice in FA treatment to evaluate the changes in Immunoglobulin and other nonimmunoglobulin parameters.

The ability of homeopathic medicines to cure different allergic conditions has been established in various clinical settings. 46, 47. But, a designed research in Food allergy has not been tried or tested using homeopathic medicines. Homoeopathy is also popular for the preventive aspect of the medical care. The literature of homeopathy abundantly talks about various complaints from specific food items and its specific curative ability.48, 49. The similimum concept of homoeopathy has an advantage when the "key note prescriptions" and prescriptions based on "uncommon peculiar characteristic symptoms" in a case of food allergy when a food item strongly induce the disease condition if no other visible causations prevail. Group of sure shot medicines for the particular food allergy also gives the room for the researcher to exploit the randomized trials to establish the efficacy in a research set up.

Prevention of tendency of food allergy is possible through the constitutional homeopathic medicine due to its ability to change the constitutional features of diseased individual 50 Similarly an allergy tendency (constitutional) can be removed or intensity can be reduced by inducing proper constitutional medicines. This will effectively reduce the emergency admissions and mortality related to food allergy. As already mentioned, many skin complaints have strong association with food allergy. This can be effectively tackled through homeopathy owing to its important holistic treatment approach. The added advantage of this approach is that the financial implications could be minimized.

Table 3 mentions the symptoms/conditions caused due to allergy to specific food items and the useful homoeopathic medicines indicated in combating the respective FA's. Table 4 mentions the homoeopathic medicines which can be used for specific FA's as gathered from various homoeopathic literature. The medicines have different intensity when it comes to the actual disease conditions. For example, if the patient has complaints from beans and peas, the individual symptoms will differentiate the medicines to be prescribed and its required potency and repetition. Though it is mentioned urticaria from eating pork is relieved by Pulsatilla, but in practice it is applicable to fatty food in general. ${ }^{51}$ Similarly aggravation to milk is well tolerated by taking either Silicea or Natrum Carb ${ }^{48}$ according to the symptom similarity. Using these medicines the cow milk allergy can be effectively treated at early stage so that the developmental disability can be prevented in children.

Table: 3 Allergic complaints from food items and its proposed medicines\#

\begin{tabular}{|l|l|l|}
\hline Symptoms/conditions & Food items & Possible homoeopathic medicines \\
\hline Urticaria & Meat & Antimonium crudum \\
\hline & Shell-fish & $\begin{array}{l}\text { Apis mellifica, Arsenicum album, Astacus fluviatilis, Camphor, Terebinthiae oleum, } \\
\text { Tetradymitum, Urtica urens }\end{array}$ \\
\hline & Fruits & Pulsatilla nigricans \\
\hline & Pork & Pulsatilla nigricans \\
\hline & Strawberries & Fragaria vesca \\
\hline Itching & Sea fish & Arsenicum album, Homarus gammarus \\
\hline
\end{tabular}




\begin{tabular}{|l|l|l|}
\hline Diarrhea & Meat & Causticum hahnemanii, Ferrum metaliicum, Leptandra virginica, Sepia succus \\
\hline Fat food & $\begin{array}{l}\text { Antimonium crudum, Calcarea fluorica, Carbo vegetabilis, Cyclamen europaeum, } \\
\text { Kali-chloricum, Magnesia sulfuric, Mandragora officinarum, Pulsatilla Nigricans, } \\
\text { Sycotic-compound, Thuja occidentalis }\end{array}$ \\
\hline Headache & fat food & $\begin{array}{l}\text { Carbo vegetabilis, Colchicum autumnale, Cyclamen europaeum, Ipecacuanha, Natrum } \\
\text { carbonicum, Natrum muriaticum, Pulsatilla Nigricans, Robinia pseudacacia, } \\
\text { Sanguinaria Canadensis, Sepia succus, Thuja occidentalis }\end{array}$ \\
\hline Cough & fat food & $\begin{array}{l}\text { Antimonium crudum, Calcarea carbonica, Carbo vegetabilis, Causticum Hahnemanii, } \\
\text { Cyclamen europaeum, Ipecaccuanha, kali-chloratum, Natrum phosphoricum, } \\
\text { Pancreatinum, Ptelea trifoliate, Pulsatilla Nigricans, Sepia succus, Sulphur, Sycotic- } \\
\text { compound, Thuja occidentalis }\end{array}$ \\
\hline
\end{tabular}

"References from Complete repertory; Cara (C)1997 Miccant Ltd; Medicines are indicative only, individualized approach is final for any prescription. Few under proved medicine has been deleted from the list

\section{Table 4 Aggravation from food items and possible homoeopathic medicines*}

\begin{tabular}{|c|c|c|}
\hline Sr.No. & $\begin{array}{l}\text { Food items } \\
\text { aggravate }\end{array}$ & Possible Important Medicines \\
\hline 1. & Ale & Gambogia, Spongia tosta, Sulphur \\
\hline 2. & Beans and peas & Bryonia alba, Calcarea carbonica, Colocynthis, Lycopodium clavatum, Petroleum \\
\hline 3. & Bread & $\begin{array}{l}\text { Antimonium crudum, Baryta carbonica, Bryonia alba, Hydrastis Canadensis, Lycopodium } \\
\text { clavatum, Natrum muriaticum, Nitric acid, Nux Vomica, Pulsatilla Nigricans, Rhus toxicodendron, } \\
\text { Sarsaparilla officinalis, Sepia succus, Sulphur, Veratrum album, Zincum metallicum }\end{array}$ \\
\hline 4. & Butter & $\begin{array}{l}\text { Carbo vegetabilis, Ferrum metallicum, Phosphorus, Ptelea trifoliate, Pulsatilla Nigricans, Sepia } \\
\text { succus, Taraxacum officinale }\end{array}$ \\
\hline 5. & Cabbage & $\begin{array}{l}\text { Bryonia alba, China officianalis, Lycopodium clavatum, Magnesia carbonica, Natrum Sulphuricum, } \\
\text { Petroleum, Pulsatilla nigricans }\end{array}$ \\
\hline 6. & Carrots & Lycopodium clavatum \\
\hline 7. & Chocolate & Borax veneta, Lithium carbonicum, Lycopodium clavatum, Pulsatilla nigricans \\
\hline 8. & Cucumber & Allium cepa, Ignatia amara, Natrum muriaticum, Rhus toxicodendron \\
\hline 9. & Eggs & Cocculus indicus, Ferrum metallicum, Pulsatilla Nigricans, Sulphur \\
\hline 10. & Fish & Fluoricum acidum, Kalium Sulphuricum, Medussa, Plumbum metallicum, Pulsatilla nigricans \\
\hline 11. & Fruit & $\begin{array}{l}\text { Aloe socotrina, Antimonium crudum, Antimonium tartaricum, Arsenicum album, Borax veneta, } \\
\text { Bryonia alba, Calcarea phosphoric, Carbo vegetabilis, Causticum hahnemanii, China officinalis, } \\
\text { Chinum arsenicosum, Cistus Canadensis, Colocynthes, Croton tiglinum, Ferrum mettalicum, } \\
\text { Ipecacuanha, Iris versicolor, Lycopodium clavatum, Magnesia muriaticum, Muriaticum acidum, } \\
\text { Natrum Arsenicum, Natrum carbonicum, Natrum Sulphuricum, Oleander, Phosphoric acid, } \\
\text { Podophyllum peltatum, Psorinum, Pulsatilla Nigricans, Rhododendron chrysanthum, Rumex } \\
\text { crispus, Selenium, Sepia succus, Veratum album }\end{array}$ \\
\hline 12. & Garlic & Phosphorus \\
\hline 13. & Meat & $\begin{array}{l}\text { Arsenicum album, Bryonia alba, Calcarea carbonica, China officinalis, Colchicum autumnale, } \\
\text { Ferrum metallicum, Kali-bichromicum, Kali-carbonicum, Lyssin, Ptelea trifoliate, Pulsatilla } \\
\text { nigricans }\end{array}$ \\
\hline 14. & Oil & Cantharis vesicatoria, Menyanthes trifoliate, Natrum muriaticum, Pulsatilla nigricans \\
\hline 15. & Onions & Ignatia amara, Lycopodium clavatum, Pulsatilla Nigricans, Sulphur, Thuja occidentalis \\
\hline 16. & Oranges & Oleander \\
\hline 17. & Oysters & $\begin{array}{l}\text { Aloe socotrina, Bromium, Colocynthis, Lycopodium clavatum, Podophylum peltatum, Pulsatilla } \\
\text { Nigricans, Sulphuricum acidum }\end{array}$ \\
\hline 18. & Pastry & $\begin{array}{l}\text { Antimonium crudum, Bryonia alba, Kali-carbonicum, Kali-chloricum, Lycopodium clavatum, } \\
\text { Phosphorus, Pulsatilla Nigricans, Veratrum album }\end{array}$ \\
\hline 19. & Pears & Veratrum album \\
\hline 20. & Plums & Mercurius corrosive \\
\hline 21. & Pork & Antimonium crudum, Carbo-vegetabilis, Colchicum autumnale, Cyclamen europaeum, Graphites, \\
\hline
\end{tabular}




\begin{tabular}{|c|c|c|}
\hline & & $\begin{array}{l}\text { Ipecacuanha, Medorrhinum, Natrum-arsenicum, Natrum carbonicum, Natrum muriaticum, } \\
\text { Pulsatilla Nigricans, Sepia succus }\end{array}$ \\
\hline 22. & Potatoes & $\begin{array}{l}\text { Alumina, Alumen, Bryonia alba, Colocynthis, Natrum-sulphuricum, Pulsatilla Nigricans, Sepia } \\
\text { succus, Silicea, Sulphur, Veratrum album. }\end{array}$ \\
\hline 23. & Rice & Ignatia amara, \\
\hline 24. & Salads & Calcarea carbonica, Pulsatilla nigricans \\
\hline 25. & Sardines & Lycopodium clavatum \\
\hline 26. & Sauerkraut & $\begin{array}{l}\text { Bryonia alba, Calcarea carbonica, China officianalis, Lycopodium clavatum, Petroleum, } \\
\text { Phosphorus, Pulsatilla nigricans }\end{array}$ \\
\hline 27. & Shell-fish & Colocynthis, Lycopodium clavatum, Urtica urens \\
\hline 28. & Sugar & Argentum-nitricum, Calcarea carbonica, Mercurius solubilis, Selenium, Sulphur \\
\hline 29. & Sweets & $\begin{array}{l}\text { Antimonium crudum, Argentum-nitricum, Chamomilla, Graphites, Ignatia amara, Ipecacuanha, } \\
\text { Mercurius solubilis, Natrum phosphoricum, Pulsatilla Nigricans, Selenium, Sulphur }\end{array}$ \\
\hline 30. & Turnips & Bryonia alba, Lycopodium clavatum, Pulsatilla nigricans \\
\hline 31. & Vinegar & $\begin{array}{l}\text { Aconitum napellus, Antimonium crudum, Arsenicum album, Belladonna, Carbo-vegetabilis, } \\
\text { Ferrum metallicum, Graphites, Natrum phosphoricum, Pulsatilla Nigricans, Sepia succus, Sulphur }\end{array}$ \\
\hline 32. & Whisky & $\begin{array}{l}\text { Arnica Montana, Arsenicum album, Calcarea carbonica, Hepar sulphuris, Lachesis, Ledum palustre, } \\
\text { Nux Vomica, Opium, Ranunculus bulbosus, Rhus Toxicodendron, Stramonium }\end{array}$ \\
\hline 33. & Wine & $\begin{array}{l}\text { Antimonium crudum, Arnica Montana, Arsenicum album, Borax veneta, Calcarea carbonica, China } \\
\text { officinalis, Cina maritime, Coffea cruda, Conium maculatum, Flouricum acidum, Gelsemium } \\
\text { sempervirens, Glonoinum, Lachesis, Ledum palustre, Lycopodium clavatum, Mercurius solubilis, } \\
\text { Naja tripudians, Natrum arsenicosum, Natrum carbonicum, Natrum muriaticum, Nux moschata, } \\
\text { Nux Vomica, Opium, Ranunculus bulbosus, Rhododendron chrysanthum, Sabadilla officinarum, } \\
\text { Selenium, Silicea, Sulphur, Zincum metallicum, Zincum phosphoricum }\end{array}$ \\
\hline
\end{tabular}

*References from Complete repertory; Carav1.4 (C)1997 Miccant Ltd; Medicines are indicative only, individualized approach is final for any prescription.

When the oysters cause complaints, homoeopathic physician generally prescribes Lycopodium or Carbo vegetabilis. 49 Allergic to fruits and meat is generally well responded to Pulsatilla nigricans.

There are single medicines covering multiple food items like Lycopodium clavatum is found to be effective in complaints eating of beans and peas, bread, cabbage, carrots, chocolates, fruits, onions, oysters, shell fish etc. But when there are multiple actions prevailing, the individualization of the patient is imperative.

Even in emergencies homeopathic medicine has valuable contribution. The anaphylaxis can be treated using different medicines especially like Apis mellifica, Urtica urens, Arsenicum album, Natrum muriaticum etc. 52

Since the food allergy and other complaints co-exist like dermatitis Calcarea carbonica, Graphites, Arsenicum album, Sulphur, Rhus toxicodendron, Sepia are few important medicines regularly used for skin complaints of children as well as in adult populations. Asthmatic complaints of children can be effectively treated using Silicea, Natrum sulphuricum, Arsenicum album etc. and a lot other medicines are also available.

\section{Conclusion:}

Food allergy is a growing health problem in almost all countries. The prevalence of FA is not uniform to all countries due to its root in the cultural, economical and consumption habits and availability of various food items. A wide range of food allergy research has been under taken all over world but India lagging behind in FA. Homoeopathic research is very minimal or nil in respect to problem of FA.
Abundant data available in various sources of Homoeopathic Materia Medica should be tested scientifically through clinical trials to evolve an effective treatment plan for the FA in all age groups.

\section{References:}

1. Abbas M, Moussa M, Akel H. Type I Hypersensitivity Reaction. 2021 Jul 21. In: StatPearls [Internet]. Treasure Island (FL): StatPearls Publishing; 2021 Jan-. PMID: 32809396.

2. Prescott S, Allen KJ. Food allergy: riding the second wave of the allergy epidemic. Pediatr Allergy Immunol. 2011 Mar; 22(2):155-60. Available from:

http://onlinelibrary.wiley.com/doi/10.1111/j.1399-

3038.2011.01145.x/pdf https://doi.org/10.1111/j.13993038.2011.01145.x

3. NIAID-Sponsored Expert Panel, Boyce JA, Assa'ad A, et al. Guidelines for the diagnosis and management of food allergy in the United States: report of the NIAID-sponsored expert panel. J Allergy Clin Immunol. 2010; 126(6 Suppl):S1-S58. Available from:

http://www.niaid.nih.gov/topics/foodallergy/clinical/documen ts/faguidelinesexecsummary.pdf https://doi.org/10.1016/j.jaci.2010.10.007

4. The PRISMA Statement; Available from: http://www.prismastatement.org/

5. Gabriel Van Loon. Charaka Samhita, Hand Book on Ayurveda, Vol.1; 2003. Available from:

http://www.rencapp.com/TamilCube_Charaka_Samhita.pdf

6. Hippocrates. On Ancient Medicine. Available from: http://classics.mit.edu/Hippocrates/ancimed.html

7. Food Allergy: a practice parameter. 2006 (96) Available from: http://www.thesuperallergycookbook.com /PDF/ FoodAllergypaper. pdf accessed on 04.11.2011 
8. WAGNER R. CLEMENS VON PIRQUET, DISCOVERER OF THE CONCEPT OF ALLERGY. Bull N Y Acad Med. 1964; 40(3):229235. Available from: http://www.ncbi.nlm.nih.gov/pmc/articles/ PMC1750523/pdf/bullnyacad med00288-0071.pdf accessed on 18.10.2012.

9. Hare F. THE FOOD FACTOR IN DISEASE. Br Med J. 1906; 1(2364):951. Available from: http://ia600500.us.archive.org/25/items/foodfactorindise01ha re/foodfactorindise01hare.pdf https://doi.org/10.1136/bmj.1.2364.951-b

10. Arthur F Coca. The Pulse Test. Available from: http://www.soilandhealth.org/02/0201hyglibcat/020108.coca. $\mathrm{pd}$

11. Ishizaka K, Ishizaka T, Hornbrook MM. Physicochemical properties of reaginic antibody. V. Correlation of reaginic activity wth gamma-E-globulin antibody. J Immunol. 1966 Dec; 97(6):840-53. Available from

http://www.ncbi.nlm.nih.gov/pubmed/4163008

12. Duncan Graham-Rowe. Lifestyle: When allergies go west; Nature 479, S2-S4 (24 November 2011) Published online 23 November 2011. Available from:

http://www.nature.com/nature/journal/v479/n7374_supp/full /479S2a.html\#auth-1 https://doi.org/10.1038/479S2a

13. Jennifer J. Schneider Chafen, Sydne Newberry, Marc Riedl, Dena M. Bravata, Margaret Maglione, Marika Suttorp, et al. Prevalence, Natural History, Diagnosis, and Treatment of Food Allergy: A Systematic Review of the Evidence; WR-757-1, August 2010, Prepared for the National Institute of Allergy and Infectious Diseases. Available from:

http://www.rand.org/content/dam/rand/pubs/working_paper s/2010/RAND_WR757-1.pdf

14. Wang J, Sampson HA. Food allergy. J Clin Invest. 2011 Mar 121(3):827-35. Epub 2011 Mar 1. Available from: http://www.jci.org/articles/view/45434/pdf https://doi.org/10.1172/JCI45434

15. Ruby Pawankar Stephen T. Holgate G. Walter Canonica Richard F. Lockey. WAO White Book on Allergy 2011-2012; World Allergy Organization. Available from: http://www.worldallergy.org/UserFiles/file/WAO-White-Bookon-Allergy_web.pdf

16. Hadley C. Food allergies on the rise? EMBO Rep (2006) 7:1080 1083 Available from:

http://www.nature.com/embor/journal/v7/n11/full/7400846. html https://doi.org/10.1038/sj.embor.7400846

17. Branum AM, Lukacs SL. Food allergy among U.S. children: trends in prevalence and hospitalizations. NCHS Data Brief. 2008 Oct;(10):1-8. Available from:

http://www.cdc.gov/nchs/data/databriefs/db10.pdf.

18. Wang J, Liu AH. Food allergies and asthma. Curr Opin Allergy Clin Immunol. 2011 Jun; 11(3):249-54. Available from: http://www.ncbi.nlm.nih.gov/pmc/articles/PMC3155248/\#!po $=2.77778$ https: $/ /$ doi.org $/ 10.1097 /$ ACI.0b013e3283464c8e

19. Ruchi S. Gupta, Elizabeth E. Springston, Manoj R. Warrier, Bridget Smith, Rajesh Kumar, Jacqueline Pongracic, Jane L. Holl. The Prevalence, Severity, and Distribution of Childhood Food Allergy in the United States. PEDIATRICS July 2011; 128(1):e9-e17; 2011-0204. Available from:

http://pediatrics.aappublications.org/content/early/2011/06/ 16/peds.2011-0204.full.pdf+html

https://doi.org/10.1542/peds.2011-0204

20. Niphadkar PV, Patil SP, Bapat MM. Chickpea-induced anaphylaxis. Allergy. 1997 Jan; 52(1):115-6. Available from: http://onlinelibrary.wiley.com/doi/10.1111/j.13989995.1997.tb02559.x/pdf https://doi.org/10.1111/j.13989995.1997.tb02559.x

21. Wong G. Patterns of food allergy outside Europe. Clinical and Translational Allergy 20111 (Suppl 1):56. Available from: http://www.ctajournal.com/content/pdf/2045-7022-1-S1-
S6.pdf Accessed on 18.12.2012. https://doi.org/10.1186/20457022-1-S1-S6

22. Kumar R, Kumari D, Srivastava P, Khare V, Fakhr H, Arora N, Gaur SN, Singh BP. Identification of IgE-mediated food allergy and allergens in older children and adults with asthma and allergic rhinitis. Indian J Chest Dis Allied Sci. 2010 Oct-Dec;52(4):217-24 Available from:

http://www.ncbi.nlm.nih.gov/pubmed/21302599

23. McBride D, Keil T, Grabenhenrich L, Dubakiene R, Drasutiene G, Fiocchi A, et al. The EuroPrevall birth cohort study on food allergy: baseline characteristics of 12,000 newborns and their families from nine European countries. Pediatr Allergy Immunol. 2012 May; 23(3):230-9. Epub 2011 Dec 23. PMID: 22192443. Available from:

http://www.ncbi.nlm.nih.gov/pubmed/22192443 https://doi.org/10.1111/j.1399-3038.2011.01254.x

24. Christie L, Hine RJ, Parker JG, Burks W. Food allergies in children affect nutrient intake and growth. J Am Diet Assoc. 2002 Nov; 102(11):1648-51. Available from:

http://www.ncbi.nlm.nih.gov/pubmed/12449289 accessed on 18.12.2012 https://doi.org/10.1016/S0002-8223(02)90351-2

25. Isolauri E, Sütas Y, Salo MK, Isosomppi R, Kaila M. Elimination diet in cow's milk allergy: risk for impaired growth in young children. J Pediatr. 1998 Jun; 132(6):1004-9. Available from: http://www.ncbi.nlm.nih.gov/pubmed/9627594 accessed on 22.12.2012. https://doi.org/10.1016/S0022-3476(98)70399-3

26. Norman F. Carvalho, Richard D. Kenney, Paul H. Carrington and David E. Hall Severe Nutritional Deficiencies in Toddlers Resulting From Health Food Milk Alternatives Pediatrics 2001;107;e46. Available from:

http://pediatrics.aappublications.org/content/107/4/e46.full.p $\mathrm{df}+\mathrm{html}$. Accessed on 22.12.2012 https://doi.org/10.1542/peds.107.4.e46

27. Cho HN, Hong S, Lee SH, Yum HY. Nutritional status according to sensitized food allergens in children with atopic dermatitis. Allergy Asthma Immunol Res. 2011; 3(1):53-7. Epub 2010 Nov 23. accessed on 22.12.2012 .Available from: http://www.ncbi.nlm.nih.gov/pmc/articles/PMC3005320/ https://doi.org/10.4168/aair.2011.3.1.53

28. Bird JA, Burks AW. Food allergy and asthma. Prim Care Respir J. 2009 Dec; 18(4):258-65. Available from: http://www.thepcrj.org/journ/vol18/18_4_258_265.pdf https://doi.org/10.4104/pcrj.2009.00036

29. Nsouli TM, Nsouli SM, Linde RE, O'Mara F, Scanlon RT, Bellanti JA. Role of food allergy in serous otitis media. Ann Allergy. 1994 Sep; 73(3):215-9. PMID: 8092554. Available from: http://www.ncbi.nlm.nih.gov/pubmed/8092554 accessed on 22.12.2012.

30. Cochrane S, Beyer K, Clausen M, Wjst M, Hiller R, Nicoletti C, et al. Factors influencing the incidence and prevalence of food allergy; Allergy. 2009 Sep; 64(9):1246-55. Epub 2009 Aug 5. Available from: http://www.ncbi.nlm.nih.gov/pubmed/19663867 https://doi.org/10.1111/j.1398-9995.2009.02128.x

31. Study of nutritional factors in food allergies and food intolerances: Published by the European Commission Directorate-General XII Science, Research and Development B1049 Brussels; 1997. Available from: http://ec.europa.eu/research/agriculture/pdf/books/study $\% 2$ 0of $\% 20$ nutritional $\% 20$ factors $\% 20$ in $\% 20$ food $\% 20$ allergies $\% 20$ and\%20food\%20intolerance.pdf accessed on 01.01.2013.

32. Patel DA, Holdford DA, Edwards E, Carroll NV. Estimating the economic burden of food-induced allergic reactions and anaphylaxis in the United States. J Allergy Clin Immunol. 2011; 128(1):110-115.e5. Epub 2011 Apr 13. Available from: http://www.ncbi.nlm.nih.gov/pubmed/21489610 https://doi.org/10.1016/j.jaci.2011.03.013

33. Liem, J.J., Huq, S., Kozyrskyj, A.L. et al. Should Younger Siblings of Peanut-Allergic Children Be Assessed by an Allergist before Being Fed Peanut? All Asth Clin Immun 2008; 4:144. Available from: http://www.aacijournal.com/content/4/4/144 https://doi.org/10.1186/1710-1492-4-4-144 
34. Hidalgo-Castro EM, del Rio-Navarro BE, Sienra-Monge JJ. Factores de riesgo de alergia alimentaria [Risk factors of food allergy]. Rev Alerg Mex. 2009 Sep-Oct; 56(5):158-64. Spanish.

35. Eggesbø M, Botten G, Stigum H, Nafstad P, Magnus P. Is delivery by cesarean section a risk factor for food allergy? J Allergy Clin Immunol. 2003 Aug; 112(2):420-6.

https://doi.org/10.1067/mai.2003.1610

36. Greer FR, Sicherer SH, Burks AW; American Academy of Pediatrics Committee on Nutrition; American Academy of Pediatrics Section on Allergy and Immunology. Effects of early nutritional interventions on the development of atopic disease in infants and children: the role of maternal dietary restriction, breastfeeding, timing of introduction of complementary foods, and hydrolyzed formulas. Pediatrics. 2008 Jan; 121(1):183-91. https://doi.org/10.1542/peds.2007-3022

37. Beyer K, Morrow E, Li XM, Bardina L, Bannon GA, Burks AW, Sampson HA. Effects of cooking methods on peanut allergenicity. J Allergy Clin Immunol. 2001 Jun; 107(6):1077-81. https://doi.org/10.1067/mai.2001.115480

38. Caleb Kelly, Venu Gangur. Sex Disparity in Food Allergy: Evidence from the Pub Med Database; Journal of Allergy Volume 2009, Article ID 159845, 7 pages. https://doi.org/10.1155/2009/159845

39. Ministry of health and family welfare (food safety and standards authority of india). Food safety and standards (packaging and labelling) regulations, 2011. Available from:

http://www.dfda.goa.gov.in/uploads/Food\%20Safety\%20and\% 20standards\%20(Packaging\%20and\%20Labelling)\%20regulati on,\%202011.pdf

40. Tsai HJ, Kumar R, Pongracic J, Liu X, Story R, Yu Y, Caruso D, Costello J, Schroeder A, Fang Y, Demirtas H, Meyer KE, O'Gorman MR, Wang X. Familial aggregation of food allergy and sensitization to food allergens: a family-based study. Clin Exp Allergy. 2009; 39(1):101-9. Epub 2008 Oct 30. https://doi.org/10.1111/j.1365-2222.2008.03111.x

41. Hourihane JO, Dean TP, Warner JO. Peanut allergy in relation to heredity, maternal diet, and other atopic diseases: results of a questionnaire survey, skin prick testing, and food challenges.
BMJ. 1996 Aug 31; 313(7056):518-21. Erratum in: BMJ 1996 Oct 26; 313(7064):1046.

https://doi.org/10.1136/bmj.313.7056.518

42. Xiumei Hong, Hui-Ju Tsai, Xiaobin Wang. Genetics of Food allergy. Curr Opin Pediatr. [Internet]. 2009 Dec; 21(6):770-776. Available from: http://www.ncbi.nlm.nih.gov/pmc/articles/PMC2892276/ https://doi.org/10.1097/MOP.0b013e32833252dc

43. Shinde V, Bawaskar R. Homoeopathy and Immunology- A Narrative Review. Indo Am. J. P. Sci. [Internet]. 2021; 08(06). Available from: http://doi.org/10.5281/zenodo.5008288

44. Hahnemann Samuel C. F. S. Organon of Medicine, 6th Edition. New Delhi: B.jain Publishers.

45. Complete Repertory, V.4. Cara (C)1997 Miccant Ltd

46. Ullmann D, Frass M. A Review of Homeopathic Research in the treatment for respiratory allergies; Alternative Medicine review. 2010; 15(1). Available from: http://www.thorne.com/altmedrev/.fulltext/15/1/48.pdf

47. Michel Van Wassenhoven. Clinical verification in homeopathy and allergic Conditions. Homeopathy (2013); 102(1):54-58. Available from:

http://www.homeopathyjournal.net/article/S14754916(12)00086-0/fulltext https://doi.org/10.1016/j.homp.2012.06.002

48. Kent J.T. Lectures on Homeopathic Materia Medica. 2nd rearranged edition, New Delhi: B Jain publishers; 2009.

49. William Boericke. Pocket manual of Homoeopathic Materia Medica. 9th ed. New Delhi: B Jain Publishers; 1987.

50. Kent J.T. Lectures on Homeopathic Philosophy. Ehrhart \& Karl Publisher; 1900.

51. Nash E. B. Leaders in Homoeopathic Therapeutics with grouping and classification. 5th ed: B. Jain Publishers; 1992.

52. Murphy Robin. Homeopathic Medical Repertory. 2nd edition. New Delhi: Indian Books \& Periodicals Publishers; 2002. 498 p. 